\title{
Komunitas Masyarakat Dan Perawatan Kesehatan Dalam Peningkatan Kualitas Hidup
}

\author{
Agustinus Hermino \\ Universitas Sari Mulia, Banjarmasin \\ Jl. Pramuka No 02 Banjarmasin, Kalimantan, Indonesia \\ Korespondensi: \\ agustinushermino@unism.ac.id; agustinus_hermino@yahoo.com
}

DOI: $10.33859 / \mathrm{dksm} . v 10 \mathrm{i} 1.437$

\begin{abstract}
Abstrak
Latar belakang: Seiring dengan perkembangan jaman, dalam beberapa tahun terakhir ini banyak perhatian yang difokuskan pada eksplorasi dampak penyakit fisik dan mental pada kualitas hidup seseorang baik secara individu maupun masyarakat secara keseluruhan. Sifat subyektif dari 'kualitas hidup' individu, merupakan konsep yang dinamis untuk diukur dan didefinisikan, tetapi bahwa secara umum dapat dipandang sebagai konsep multidimensi yang menekankan pada persepsi diri dari keadaan pikiran seseorang saat ini

Tujuan: penulisan ini bertujuan untuk memberikan pemahaman tentang peran masyarakat dalam memahani pentingnya kesehatan di era global ditinjau dari perspektif akademis. Pada sektor kesehatan pemahaman kesehatan menjadi sangat pentingnya karena akan menunjukkan pada kualitas hidup seseorang, tetapi hal ini tidak cukup secara individu karena diperlukan pemahaman secara menyeluruh terhadap masyarakat tentang makna kesehatan dan perawatan kesehatan.

Metode: penulisan ilmiah ini adalah dengan melakukan analisa akademis dari dari berbagai sumber rujukan relevan sehingga menemukan makna teoritis baru dalam rangka menjawab tantangan yang terjadi di masyarakat.

Hasil: Berdasarkan berbagai sumber rujukan yang ada, dapat disimpulkan bahwa kesehatan merupakan gaya hidup yang bertujuan untuk mencapai kesejahteraan fisik, emosional, intelektual, spiritual, dan lingkungan. Penggunaan langkah-langkah kesehatan dapat meningkatkan stamina, energi, dan harga diri, kemudian meningkatkan kualitas hidup. Dengan demikian maka konsep kesehatan memungkinkan adanya variabilitas individu. Kesehatan dapat dianggap sebagai keseimbangan aspek fisik, emosional, psikologis, sosial dan spiritual dari kehidupan seseorang.
\end{abstract}

Kata kunci: masyarakat, perawatan kesehatan, kualitas hidup 
Society Community and Health Care in Improving Quality of Life

\begin{abstract}
Background: Along with the development of the era, in recent years there has been a lot of attention focused on exploring the impact of physical and mental illness on the quality of life of a person both individually and as a whole. The subjective nature of an individual's 'quality of life' is a dynamic concept to measure and define, but that in general can be seen as a multidimensional concept that emphasizes self-perception of one's current state of mind

Aim: purpose of this study is to provide an understanding the role of community in understanding the importance of health in the global era from an academic perspective. In the health sector understanding of health is very important because it will show the quality of life of a person, but this is not enough individually because a comprehensive understanding of the meaning of health and health care is needed.

Method: The method of scientific writing is to carry out academic analysis from various relevant reference sources, and find new theoretical meanings in order to answer the challenges that occur in society.

Keyword: Community, Society, Health Care, Quality oflife

Resullt : Based on various academic reference, it can be concluded that health is a lifestyle that aims to achieve physical, emotional, intellectual, spiritual, and environmental well-being. The use of health measures can increase stamina, energy, and self-esteem, then improve the quality of life. Thus the concept of health allows for individual variability. Health can be considered as a balance of physical, emotional, psychological, social and spiritual aspects of one's life.
\end{abstract}

Keywords: community, health care, quality of life 
Dinamika Kesehatan Jurnal Kebidanan dan Keperawatan Vol 10 No. 1 Juli 2019 ( ISSN: 2086-3454 EISSN: 2549-4058)

url: http://ojs.dinamikakesehatan.unism.ac.id DOI : https://doi.org/10.33859/dksm.v10i1

Komunitas Masyarakat Dan Perawatan Kesehatan Dalam Peningkatan Kualitas Hidup

\section{Latar belakang}

Seiring dengan perkembangan jaman, dalam beberapa tahun terakhir ini banyak perhatian yang difokuskan pada eksplorasi dampak penyakit fisik dan mental pada kualitas hidup seseorang baik secara individu maupun masyarakat secara keseluruhan. Demikian pula pada pengukuran masalah psikososial dalam hal tindakan biomedis telah terbukti memainkan peran penting untuk memastikan hasil kesehatan seseorang sebagai pasien dari perspektif dokter dan pasien, dan merupakan ukuran hasil yang penting ketika mengevaluasi pengobatan (Banomi, et al, 2000). Selain itu, evaluasi berkelanjutan terhadap kualitas hidup pada seseorang dalam hidup sehat normal, dan populasi umum tertentu, seperti orang tua, juga telah mendapat perhatian secara luas saat ini berkenaan dengan peningkatan kualitas hidup. Sifat subyektif dari 'kualitas hidup' individu, merupakan konsep yang dinamis untuk diukur dan didefinisikan, tetapi bahwa secara umum dapat dipandang sebagai konsep multidimensi yang menekankan pada persepsi diri dari keadaan pikiran seseorang saat ini, dimana tantangan utama dalam menentukan kualitas hidup adalah pada eksplorasi domain mana yang harus dicakup dalam definisi keseluruhan konstruk kehidupan seseorang (Aaronson, et al 1993). Dengan demikian maka perjalanan kualitas hidup seseorang dapat menunjukkan bahwa untuk memperoleh penjelasan yang efektif, penting untuk melihat kualitas hidup sebagai konsep yang terdiri dari sejumlah nilai sosial, lingkungan, psikologis dan fisik.

\section{Metode :}

\section{Kualitas Hidup}

Konsep kualitas hidup secara luas mencakup bagaimana seorang individu mengukur 'kebaikan' berbagai aspek kehidupan mereka. Evaluasi ini mencakup reaksi emosional seseorang terhadap kejadian kehidupan, disposisi, kepuasan dan kepuasan hidup, dan kepuasan dengan pekerjaan dan hubungan pribadi (Bradley, 2001; Bowling, 1997; Clarke, at al 2000). Dalam literatur, istilah 'kualitas hidup' juga sering disebut sebagai 'kesejahteraan'. Namun, terdapat sejumlah tantangan untuk mengembangkan pemahaman yang bermakna tentang kualitas hidup dan/atau literatur kesejahteraan (Clarke, 
et al 2000; Snoek, 2000; Theofilu \&

Panagiotaki, 2011).

Pada bidang kualitas hidup, dapat

dimaknai bahwa kesejahteraan digunakan untuk merujuk pada kondisi kehidupan obyektif yang berlaku untuk suatu populasi secara umum, sementara kualitas hidup seharusnya lebih terbatas pada penilaian subyektif individu tentang kehidupan mereka karena apa yang dirasakan setiap orang sebagai individu sebagai sifat evaluatif dari istilah tersebut. Hari ini, perbedaan ini telah hilang. Istilah-istilah tersebut sering tidak terdefinisi atau digunakan secara tidak konsisten atau bergantian dalam penelitian. Dalam beberapa kasus, satu istilah bahkan digunakan untuk mendefinisikan yang lain (Theofilou \& Panagiotaki, 2012).

Kurangnya perbedaan sebagian dapat ditelusuri ke beberapa konseptualisasi kualitas hidup yang telah berkembang selama bertahun-tahun (Ubel, at al, 2003), dimulai dengan pendekatan ekonomi yang populer di akhir 1960-an dan 1970-an ketika kualitas hidup sedang dinilai dengan langkah-langkah kuantitatif dan tingkat pengangguran. Sebagai reaksi terhadap pendekatan kuantitatif yang kaku terhadap subjek ini, para peneliti mulai menanyakan pengalaman subyektif individu dalam kehidupan mereka dengan keyakinan bahwa langkah-langkah obyektif saja merupakan tindakan yang tidak lengkap.

Lebih lanjut hilangnya perbedaan dalam pendefinisian persyaratan makna kualitas hidup adalah pengakuan bahwa kualitas hidup/kesejahteraan memiliki dua komponen obyektif yaitu, komponen eksternal untuk individu dan diukur oleh 'orang lain'; dan komponen subjektif yaitu, penilaian pribadi dari kehidupan seseorang sendiri atau aspek kehidupan tertentu menggunakan ukuran kepuasan, kebahagiaan, atau skala penilaian diri lainnya. Dengan demikian mempertahankan perbedaan konseptual antara dua jenis tindakan, jelas bahwa mereka yang mengikuti tidak. Di sini, kedua istilah tersebut akan digunakan secara bergantian. Banomi, et al. (2000) merangkum beberapa komponen umum kesejahteraan subyektif, terutama berfokus pada faktor top-down yang mewakili faktor individu (seperti nilai dan tujuan) yang memengaruhi kesejahteraan. 
Komunitas untuk Kesehatan

Didefinisikan secara luas, komunitas adalah kumpulan orang yang berinteraksi satu sama lain dan yang kepentingan atau karakteristiknya memberi mereka rasa persatuan dan kepemilikan. Komunitas adalah sekelompok orang di area geografis yang ditentukan dengan tujuan dan sasaran yang sama dan potensi untuk berinteraksi satu sama lain dalam suasanan yang saling melengkapi. Fungsi komunitas mana pun termasuk pentingnya rasa memiliki dan adanya identitas bersama dalam pemaknaan: nilai, norma, komunikasi, dan perilaku pendukung anggotanya. Beberapa komunitas pada umumnya terdapat beberapa kondisi seperti: a) komunitas yang mungkin berbagi hampir semua hal; dan b) komunitas lain (besar, tersebar dan terdiri dari individu) yang mungkin hanya berbagi minat yang sama dan keterlibatan dalam tujuan tertentu.

Demikian pula, suatu komunitas kesehatan sering didefinisikan oleh batas geografisnya, keberminatan dalam pemerhatian aspek kesehatan, dan oleh karenanya disebut komunitas kesehatan untuk wilayah tertentu atau geografis. Contoh, adalah komunitas anti

rokok pada kota tertentu. Dalam hal ini kota atau lingkungan adalah komunitas geografis, sedangkan anti rokok adalah aspek pemerhatian kesehatan yang diminati. Komunitas yang dibatasi oleh batas geografis dan pemerhatian kesehatan tertentu menjadi target yang jelas untuk analisis kebutuhan kesehatan untuk menjadi dasar perencanaan program kesehatan dan komunitas geografis juga mudah dimobilisasi untuk bertindak.

Komunitas juga dapat diidentifikasi dengan minat atau tujuan bersama. Sekumpulan orang, meskipun mereka tersebar luas secara geografis, dapat memiliki minat atau tujuan yang mengikat anggota-bersamasama disebut komunitas kepentingan bersama, misal penyandang cacat yang tersebar di luar kota besar dapat muncul sebagai komunitas melalui kepentingan bersama dalam kebutuhan mereka akan akses yang lebih baik untuk kursi roda atau fasilitas cacat lainnya (Aaronson, et al, 1993).

Komunitas memiliki tiga fitur, yaitu: lokasi, populasi, dan sistem sosial. Pertama, lokasi: setiap komunitas fisik melakukan 
Dinamika Kesehatan Jurnal Kebidanan dan Keperawatan Vol 10 No. 1 Juli 2019 ( ISSN: 2086-3454 EISSN: 2549-4058)

url: http://ojs.dinamikakesehatan.unism.ac.id DOI : https://doi.org/10.33859/dksm.v10i1

Komunitas Masyarakat Dan Perawatan Kesehatan Dalam Peningkatan Kualitas Hidup

keberadaannya sehari-hari di lokasi geografis

tertentu. Kesehatan komunitas dipengaruhi

oleh lokasi ini, termasuk penempatan layanan,

fitur geografis. Kedua, populasi: terdiri dari

agregat khusus, tetapi semua orang yang berbeda yang hidup dengan batas komunitas.

Ketiga, sistem sosial: berbagai bagian sistem

sosial masyarakat yang berinteraksi dan

mencakup sistem kesehatan, sistem keluarga,

sistem ekonomi, dan sistem pendidikan.

\section{Kesehatan}

Kesehatan didefinisikan sebagai

keadaan kesejahteraan fisik, mental dan sosial

bukan hanya tidak adanya penyakit atau kelemahan. Kesehatan, dalam filosofi holistiknya sangat berbeda dari pengaturan perawatan akut. Kesehatan fisik menyiratkan fungsi mekanistik tubuh. Kesehatan mental berarti kemampuan untuk berpikir jernih dan koheren dan ada hubungannya dengan pemikiran dan perasaan seseorang dan bagaimana seseorang tersebut menangani masalah yang dihadapi. Seseorang yang sehat secara mental memiliki kapasitas untuk hidup bersama orang lain, untuk memahami kebutuhan mereka, dan untuk mencapai hubungan yang saling memuaskan.

Kesehatan sosial mengacu pada kemampuan untuk: a) membuat dan memelihara hubungan dengan orang lain; b) berinteraksi dengan baik dengan orang-orang dan lingkungan. Kesehatan dapat menunjukkan kemampuan untuk beradaptasi dengan lingkungan yang berubah untuk tumbuh dan menua, untuk penyembuhan ketika rusak, untuk penderitaan dan untuk harapan kematian yang damai. Demikian pula kesehatan dapat dimaknai sebagai kemampuan seseorangf berpikir secara konkrit, obyektif dalam norma dan kepatutan yang layak dalam sebuah atau suatu sistem (misal: keluarga, atau masyarakat) dalam rangka untuk merespons secara adaptif terhadap berbagai tantangan lingkungan.

Clarke (2000) melihat kebalikan dari kesehatan sebagai tidak ada kesehatan dan sebaliknya dari penyakit sebagai tidak ada penyakit. Lebih jauh, kematian tidak dipandang sebagai penyakit pamungkas tetapi sebagai bagian alami dari pertumbuhan dan perkembangan. Dia juga menganggap 
Dinamika Kesehatan Jurnal Kebidanan dan Keperawatan Vol 10 No. 1 Juli 2019 ( ISSN: 2086-3454 EISSN: 2549-4058)

url: http://ojs.dinamikakesehatan.unism.ac.id DOI : https://doi.org/10.33859/dksm.v10i1

Komunitas Masyarakat Dan Perawatan Kesehatan Dalam Peningkatan Kualitas Hidup

interaksi individu dengan ekologi sebagai

pengaruh penting pada kesehatan dan

penyakit. Kesehatan juga dikonseptualisasikan

sebagai sumber kehidupan sehari-hari. Ini

adalah ide positif yang menekankan sumber daya sosial dan pribadi dan kemampuan fisik.

Setiap orang memiliki persepsi pribadi

terhadap kesehatan. Beberapa orang

menggambarkan kondisi kesehatan mereka

baik meskipun sebenarnya mereka mungkin

memiliki satu atau lebih penyakit yang

didiagnosis. Itu karena setiap orang merasakan

kesehatan dalam kaitannya dengan harapan

dan nilai-nilai pribadi (Snoek, 2000). Konsep

kesehatan harus memungkinkan adanya

variabilitas individual. Kesehatan adalah

keadaan dinamis di mana orang tersebut secara

konstan beradaptasi dengan perubahan dalam

lingkungan internal dan eksternal. Misalnya,

seseorang dapat melihat dirinya sehat saat

mengalami infeksi pernapasan.

Kesehatan adalah gaya hidup yang bertujuan untuk mencapai kesejahteraan fisik, emosional, intelektual, spiritual, dan lingkungan. Penggunaan langkah-langkah kesehatan dapat meningkatkan stamina, energi, dan harga diri, kemudian meningkatkan

kualitas hidup. Konsep kesehatan juga memungkinkan adanya variabilitas individu. Kesehatan dapat dianggap sebagai keseimbangan aspek fisik, emosional, psikologis, sosial dan spiritual dari kehidupan seseorang. Ini adalah keadaan yang dinamis (Bowling, 1997). Setiap orang akan mendefinisikan kesehatan dalam kaitannya dengan harapan pribadi. Perilaku kesehatan adalah perilaku yang mendorong fungsi yang sehat dan membantu mencegah penyakit. Ini termasuk, misalnya, manajemen stres, kesadaran gizi, dan kebugaran fisik.

\section{Makna Kesehatan}

Terdapat berbagai makna konsep kesehatan. Beberapa makna didasarkan secara sempit pada ada atau tidak adanya penyakit yang dapat didefinisikan. Lainnya didasarkan lebih konseptual pada kepercayaan kesehatan, kesejahteraan dan holisme. Kesehatan diartikan sebagai tidak adanya tanda dan gejala penyakit atau cedera; dengan demikian kebalikan dari kesehatan adalah penyakit. Makna kesehatan sebagai keadaan relatif bebas 
Dinamika Kesehatan Jurnal Kebidanan dan Keperawatan Vol 10 No. 1 Juli 2019 ( ISSN: 2086-3454 EISSN: 2549-4058) url: http://ojs.dinamikakesehatan.unism.ac.id DOI : https://doi.org/10.33859/dksm.v10i1

Komunitas Masyarakat Dan Perawatan Kesehatan Dalam Peningkatan Kualitas Hidup

dari penyakit, dan kondisi homeostasis relatif.

Karena itu, penyakit adalah sesuatu yang terjadi pada seseorang.

Banyak penyedia layanan kesehatan fokus pada kepercayaan tanda dan gejala penyakit dan menyimpulkan bahwa ketika ini tidak ada lagi, orang tersebut sehat (Sousa \& Lyubomirsky, 2001). Terhadap hal ini kondisi tersebut mungkin tidak mempertimbangkan kepercayaan kesehatan seseorang atau gaya hidup seseorang.

\section{Lingkungan Kesehatan}

Lingkungan ini membantu

mengidentifikasi penyebab suatu penyakit atau dalam memaknai sebuah makna kesehatan baik secara individu maupun dalam masyarakat. Dalam lingkungan ini, terdapat tiga makna yang perlu dicermati, yaitu: a) tuan rumah: mengacu pada orang (atau kelompok) yang mungkin berisiko atau rentan terhadap suatu penyakit; b) agen: adalah faktor apa pun (internal atau eksternal) yang dapat menyebabkan penyakit dengan kehadirannya; dan c) lingkungan: merujuk pada faktor-faktor tersebut (fisik, sosial, ekonomi, emosional, spiritual) yang dapat menciptakan

kemungkinan atau kecenderungan bagi orang tersebut untuk terserang penyakit.

Dalam kesehatan dan penanganan kesehatan, terdapat hubungan antara keyakinan dan tindakan seseorang (Theofilou \& Panagiotaki, 2011). Faktor-faktor yang memengaruhi keyakinan seseorang tersebut, seperti: a) harapan pribadi dalam kaitannya dengan kesehatan dan penyakit; b) pengalaman sebelumnya dengan penyakit atau kesehatan; serta c) usia dan status perkembangan.

Kepercayaan kesehatan adalah sebuah gagasan, keyakinan, dan sikap seseorang tentang kesehatan dan penyakit. Terhadap hal ini pemahaman seseorang mungkin didasarkan pada informasi faktual, informasi yang salah, akal sehat atau mitos, atau kenyataan atau harapan yang salah, sehingga kepercayaan kesehatan biasanya mempengaruhi perilaku kesehatan, pengaruh ini bisa positif atau negatif.

Kesehatan Kepercayaan atau Health Belief (HB), kondisi ini memberikan pemaknaan berkenaan dengan adanya kehidupan sehari-hari terhadap kualitas hidup, 
dimana: a) kepercayaan dapat berkontribusi dalam mengatasi hubungan antara keyakinan dan perilaku orang; b) kepercayaan kesehatan dapat memberikan cara untuk memahami dan memprediksi bagaimana klien akan berperilaku sehubungan dengan kesehatan mereka dan bagaimana mereka akan mematuhi terapi perawatan kesehatan.

Komponen dalam HB meliputi: a) komponen pertama, yaitu persepsi individu. Persepsi individu tentang kerentanan terhadap penyakit; b) komponen kedua, yaitu faktor memodifikasi. Persepsi individu tentang keseriusan penyakit. Persepsi ini dipengaruhi dan dimodifikasi oleh variabel demografis dan sosial-psikologis, ancaman penyakit yang dirasakan dan isyarat untuk bertindak; c) komponen ketiga (kemungkinan aksi), yaitu kemungkinan bahwa seseorang akan mengambil tindakan pencegahan timbul dari persepsi orang tersebut tentang manfaat dan hambatan untuk mengambil tindakan. Tindakan pencegahan dapat meliputi: modifikasi/perubahan gaya hidup, peningkatan kepatuhan terhadap terapi medis atau mencari saran atau perawatan medis.
Berdasarkan pemaknaan diatas maka implikasi HB untuk keperawatan kesehatan adalah dalam rangka berkenaan membantu perawat untuk memahami faktor-faktor yang mempengaruhi klien terhadap: a) persepsi; b) keyakinan dan perilaku; c) merencanakan perawatan yang akan paling efektif membantu klien dalam menjaga atau memulihkan kesehatan dan mencegah penyakit.

Kesehatan diakui sebagai proses yang berkelanjutan menuju fungsi potensial tertinggi seseorang. Proses ini melibatkan orang, keluarga, dan komunitas (Clarke, et al, 2000). Terhadap hal ini kesehatan dicerminkan sebagai pengalaman orang yang hidup dengan cahaya kesehatan yang baik, hidup dengan gaya kesehatan yang baik dengan energi untuk dikembangkan dengan sangat baik.

\section{Kesehatan Holistik}

Holisme berasal dari kata Yunani yaitu holos yang berarti keseluruhan. Holisme dipandang sebagai model kesehatan baru yang mengikuti perkembangan jaman, tetapi sebenarnya itu bukan hal baru sama sekali. Holisme telah menjadi tema utama dalam 
humaniora, tradisi politik dan pembiasaan

hidup di sepanjang sejarah. Holisme adalah pendekatan yang berbeda untuk kesehatan yaitu mengakui dan menghormati interaksi pikiran, tubuh, dan jiwa seseorang dalam lingkungan.

Holisme dipandang pula sebagai penangkal bagi pendekatan otomatisasi sains kontemporer (Ubel, et al, 2003). Suatu pendekatan otomatisasi yang memisahkan beberapa hal-hal, seperti memeriksa susuatu sepotong demi sepotong dalam upaya untuk memahami gambaran yang lebih besar dengan memeriksa molekul atau atom yang lebih kecil. Holisme didasarkan pada kepercayaan bahwa orang-orang (atau bahkan bagian-bagian mereka) tidak dapat sepenuhnya dipahami jika diperiksa hanya dalam bagian-bagian yang terpisah dari lingkungan mereka. Orang dipandang sebagai sebuah sistem energi yang berubah.

\section{Kesehatan dan penyakit}

Dari pada berfokus pada menyembuhkan penyakit, asuhan keperawatan berbasis masyarakat berfokus pada peningkatan kesehatan dan mencegah penyakit. Karena itu, filosofi holistik ini sangat berbeda dengan pengaturan perawatan akut.

Peningkatan kesehatan tidak dilihat sebagai hasil dari jumlah dan jenis layanan medis atau ukuran rumah sakit. Perawatan yang diberikan dalam pengaturan perawatan akut biasanya diarahkan untuk menyelesaikan masalah kesehatan langsung. Di masyarakat, perawatan berfokus pada memaksimalkan potensi individu untuk perawatan diri terlepas dari cedera atau penyakit apa pun. Klien memikul tanggung jawab untuk keputusan perawatan kesehatan dan penyediaan perawatan. Di mana kesehatan adalah inti dari perawatan, kemampuan klien untuk berfungsi menjadi perhatian utama.

Program berbasis pendidikan dan komunitas dapat dirancang untuk mengatasi gaya hidup. Strategi perlindungan kesehatan terkait dengan langkah-langkah lingkungan atau peraturan yang memberikan perlindungan pada kelompok populasi besar. Perlindungan kesehatan melibatkan fokus masyarakat luas. Layanan pencegahan termasuk konseling, skrining, imunisasi, atau intervensi 
Dinamika Kesehatan Jurnal Kebidanan dan Keperawatan Vol 10 No. 1 Juli 2019 ( ISSN: 2086-3454 EISSN: 2549-4058)

url: http://ojs.dinamikakesehatan.unism.ac.id DOI : https://doi.org/10.33859/dksm.v10i1

Komunitas Masyarakat Dan Perawatan Kesehatan Dalam Peningkatan Kualitas Hidup

kemoprofilaksis untuk individu dalam

pengaturan klinis.

Fokus pencegahan adalah konsep kunci

keperawatan berbasis masyarakat. Pencegahan

dikonseptualisasikan pada tiga tingkatan: a)

tingkat pencegahan primer; b) tingkat

pencegahan sekunder; c) tingkat pencegahan

tersier. Dengan demikian maka kontinum

kesehatan adalah perbandingan visual dari

kesehatan yang meselaraskan pada

pemahaman perkembangan jaman dengan

pandangan kesehatan tradisional tentang

kesehatan. Pada makna tersebut maka

seseorang akan mengevaluasi tingkah laku

hidupnya pada saat tertentu, belajar tentang pilihan yang tersedia, dan tumbuh menuju aktualisasi diri dengan mengikat keluar dari pilihan yang ada untuk mendapatkan kesehatan sesuai dengan perkembangan jaman.

\section{Praktek kesehatan masyarakat}

$$
\text { Praktek kesehatan masyarakat }
$$

merupakan bagian dari upaya kesehatan masyarakat yang lebih besar yang berkaitan dengan pelestarian dan peningkatan kesehatan populasi dan komunitas tertentu. Praktik kesehatan masyarakat menggabungkan enam elemen dasar: yaitu pertama, promosi kesehatan: a) hal ini mencakup semua upaya yang berusaha mendekatkan orang untuk kesejahteraan optimal atau tingkat kesehatan yang lebih tinggi; b) ini adalah kombinasi dari dukungan pendidikan dan lingkungan untuk tindakan dan kondisi kehidupan yang kondusif bagi kesehatan. Kedua, pencegahan masalah kesehatan, hal ini menyangkut upaya pemberian pemahaman kepada masyarakat khususnya berkenaan dengan kesehatan lingkungan, kesehatan dalam keluarga, dan kesehatan untuk diri sendiri. Kondisi ini tentunya sangat berpengaruh pada tingkat pendidikan pada seseorang maupun masyarakat.

Ketiga, pengobatan kelainan: a) fokus pada akhir penyakit dari kontinum dan merupakan aspek perbaikan dari praktik kesehatan masyarakat. Hal ini dipraktikkan melalui: (i) layanan langsung kepada orangorang dengan masalah kesehatan, misalnya kunjungan rumah untuk orang lanjut usia, penyakit kronis, dll; (ii) layanan tidak langsung, misalnya membantu orang-orang 
Dinamika Kesehatan Jurnal Kebidanan dan Keperawatan Vol 10 No. 1 Juli 2019 ( ISSN: 2086-3454 EISSN: 2549-4058)

url: http://ojs.dinamikakesehatan.unism.ac.id DOI : https://doi.org/10.33859/dksm.v10i1

Komunitas Masyarakat Dan Perawatan Kesehatan Dalam Peningkatan Kualitas Hidup

dengan masalah kesehatan untuk mendapatkan

perawatan dan rujukan; (iii) pengembangan

program untuk memperbaiki kondisi yang

tidak sehat; misalnya alkoholisme,

penyalahgunaan narkoba, dll. Keempat,

rehabilitasi. Hal ini melibatkan upaya-upaya

yang berupaya mengurangi disabilitas,

sebanyak mungkin, dan memulihkan fungsi;

misalnya rehabilitasi stroke. Kelima, Evaluasi.

Hal ini adalah proses di mana praktik dianalisis, dinilai, dan ditingkatkan sesuai dengan tujuan dan standar yang ditetapkan. Ini membantu untuk memecahkan masalah dan memberikan arahan untuk perencanaan perawatan kesehatan di masa depan. Keenam, penelitian. Hal ini adalah penyelidikan sistematis yang membantu menemukan fakta yang memengaruhi kesehatan masyarakat dan praktik kesehatan masyarakat, menyelesaikan masalah, dan mengeksplorasi metode peningkatan layanan kesehatan.

\section{Perawatan Kesehatan Masyarakat}

Perawatan kesehatan masyarakat dapat didefinisikan sebagai sintesis keperawatan dan praktik kesehatan masyarakat yang diterapkan untuk mempromosikan dan melindungi kesehatan populasi. Ini adalah bidang keperawatan khusus yang berfokus pada kebutuhan kesehatan masyarakat, kelompok agregasi, dan khususnya populasi rentan (Snoek, 2000). Ini adalah praktik yang berkelanjutan dan komprehensif yang ditujukan kepada semua kelompok anggota masyarakat. Ini menggabungkan semua elemen dasar keperawatan klinis, profesional dengan kesehatan masyarakat dan praktik masyarakat. Itu Keperawatan Kesehatan Masyarakat 19 mensintesis tubuh pengetahuan dari ilmu kesehatan masyarakat dan teori keperawatan profesional untuk meningkatkan kesehatan masyarakat.

Terdapat setidaknya enam karakteristik keperawatan kesehatan masyarakat yang patut dicermati, yaitu: 1) bidang keperawatan khusus; 2) praktik penggabungan kesehatan masyarakat dengan keperawatan; 3) fokus pada populasi; 4) penekanan pada kesehatan dan penyakit; 5) pelibatan kolaborasi antardisiplin; 6) promosi tanggung jawab dan perawatan diri klien 
Dinamika Kesehatan Jurnal Kebidanan dan Keperawatan Vol 10 No. 1 Juli 2019 ( ISSN: 2086-3454 EISSN: 2549-4058) url: http://ojs.dinamikakesehatan.unism.ac.id DOI : https://doi.org/10.33859/dksm.v10i1

Komunitas Masyarakat Dan Perawatan Kesehatan Dalam Peningkatan Kualitas Hidup

Perawatan kesehatan masyarakat berlangsung

dalam berbagai pengaturan yang meliputi peningkatan kesehatan, pencegahan penyakit, pemeliharaan kesehatan, pemulihan, koordinasi, manajemen dan evaluasi perawatan individu, keluarga, dan kelompok agregat, termasuk masyarakat. Dalam pengaturan komunitas, perawatan berfokus pada memaksimalkan potensi individu untuk perawatan diri terlepas dari cedera atau penyakit apapun.

Perubahan dalam layanan perawatan kesehatan menghasilkan perubahan dalam perawatan juga. Pengaturan diubah ke komunitas dan terutama ke rumah. Maksud perawatan bukan untuk memperbaiki dengan perawatan tetapi untuk meningkatkan kualitas hidup dan mendukung tindakan yang membuat hidup klien senyaman mungkin.

\section{Pengaturan Perawatan Akut}

Istilah ini digunakan untuk orang yang menerima perawatan rumah sakit intensif. Perawatan yang diberikan dalam pengaturan perawatan akut biasanya diarahkan untuk menyelesaikan masalah kesehatan langsung.
Pengaturan perawatan akut adalah bagian dari pengaturan rumah sakit yang juga dapat digunakan sebagai klinik rawat jalan atau klien bedah sehari-hari atau mereka membutuhkan perawatan yang sangat teknis. Banyak dari klien ini memiliki kondisi yang mengancam jiwa dan membutuhkan pemantauan ketat dan perawatan konstan. Oleh karena itu, asuhan keperawatan akut berbeda dari asuhan keperawatan berbasis komunitas.

\section{Hasil dan Kesimpulan :}

Perawatan kesehatan masyarakat adalah seni dan ilmu untuk memperpanjang hidup, mempromosikan kesehatan dan mencegah penyakit melalui organisasi upaya masyarakat. Keperawatan kesehatan masyarakat mengacu pada komposisi layanan keperawatan dan promosi kesehatan populasi. Hal ini bertujuan untuk: 1) meningkatkan pemahaman pentingnya kualitas hidup; 2) kontrol epidemi masyarakat; 3) mencegah penularan infeksi; 4) memberikan pendidikan tentang prinsip-prinsip dasar kebersihan pribadi; 5) mengatur layanan medis dan keperawatan untuk diagnosis dini, pencegahan dan pengobatan penyakit. 


\section{Daftar Pustaka}

Aaronson, N. K., Ahmedzai, S., Bergman, B., Bullinger, M., Cull, A., Duez, N. J., Takeda, F. (1993). The European Organization for Research and Treatment of Cancer QLQ-C30: A quality-of-life instrument for use in international clinical trials in oncology. Journal of the National Cancer Institute, 85, 365-376. doi:10.1093/jnci/85.5.365

Bonomi, A. E., Patrick, D. L., Bushnell, D. M., \& Martin, M. (2000). Validation of the United States' version of the World Health Organization Quality of Life (WHOQOL) instrument. Journal of Clinical Epidemiology, 53, 1-12. doi:10.1016/S0895-4356(99)00123-7

Bowling, A. (1997). Measuring health: $A$ review of quality of life measurement scales (2nd ed.). Buckingham: Open University Press.

Bradley, C. (2001). Importance of differentiating health status from quality of life. Lancet, 357, 7-8. doi:10.1016/S0140-6736(00)03562-5

Clarke, P. J., Marshall, V. W., Ryff, C. D., \& Rosenthal, C. J. (2000). Well being in Canadian seniors: Findings from the Canadian Study of Health and Aging. Canadian Journal on Aging, 19, 139159.

doi:10.1017/S0714980800013982

Snoek, F. J. (2000). Quality of life: A closer look at measuring patients' wellbeing. Diabetes Spectrum, 13(1), 2428.

Sousa, L., \& Lyubomirsky, S. (2001). Life satisfaction. In J. Worell (Ed.), Encylopedia of women and gender: Sex similarities and differences and the impact of society on gender (Vol. 2, pp. 667-676). San Diego, CA: Academic Press
Theofilou, P., \& Panagiotaki, H. (2011). The association between musculoskeletal disorders and quality of life. [Editorial]. Journal of Trauma \& Treatment, 1, Article e101.

Theofilou, P., \& Panagiotaki, H. (2012). Health-related quality of life measurement among hypertensive patients. [Editorial]. Journal of Clinical Trials, 1, Article e102.

Ubel, P. A., Loewenstein, G., \& Jepson, C. (2003). Whose quality of life? A commentary exploring discrepancies between health state evaluations of patients and the general public. Quality of Life Research, 12(6), 599607. doi:10.1023/A:1025119931010 